Journal of African Real Estate Research

Volume 3, Issue 1

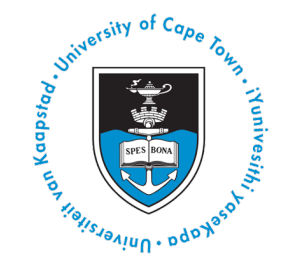

\title{
Challenges to Land Registration in Kaduna State, Nigeria
}

\author{
Chukwuma C. Nwuba ${ }^{1}$, and Siddique R. Nuhu \\ 1,2 Department of Estate Management Kaduna Polytechnic, Kaduna, Nigeria
}

To cite this article: Nwuba, C. C., \& Nuhu, S. R. (2018). Challenges to Land Registration in Kaduna State, Nigeria. Journal of African Real Estate Research, 3(1): pp.141-172. DOI: 10.15641/jarer.v1i1.566.

\begin{abstract}
:
Nigeria's land registration programmes are beset with challenges. The linkage between land, the government and the people create a complex system with unique obstacles. This research investigates the challenges of land registration in Nigeria with an in-depth study of Kaduna State. The objective is to ascertain the frequency of land registration and the factors that stand as challenges to land registration from the perspectives of households, consultants in land transactions, and the Kaduna Geographic Information System (KADGIS). The results indicate a low level of land registration in which challenges include ignorance, affordability problems, inefficient registration processes, corruption, and inadequate skilled workforce with the human capital to implement the programmes. The research has implications for both land and housing markets in Nigeria and Africa in general.
\end{abstract}

Keywords: Land Market; Land Title Registration; Land Tenure Formalisation; Security of Tenure; Title Registration; Nigeria

\section{Introduction}

Rapid urbanisation has placed urban land in African countries under pressure. In many of these countries, access to urban residential land by households is limited and thus an issue of public concern. Africa and Asia are the fastest urbanising continents and Nigeria together with India and China expected to account for $37 \%$ of the projected growth of the world's urban population between 2014 and 2050 (United Nations Department of Economic and Social Affairs, 2014). In most African countries, houses are in short supply and the land market appears to be moribund (Tibaijuka, 2004). In Nigeria, access to urban land is such a sensitive matter that the security of land rights can be precarious. This is reflected in the difficulty in searching for information for land transactions and the inefficient production of formal land title documents by the government (Federal Ministry of Housing and Urban Development,

\footnotetext{
1 nwuba.chuks@gmail.com

2nusid19@gmail.com
} 
2006). The result is that in many cases, urban land purchasers find it difficult to confirm the validity of land titles they want to acquire. Indeed, households' access to urban land with secure tenure, especially for the low and middleincome groups, has become an important factor in governance. One way to achieve security of land rights is through land registration.

Land title registration, with formal evidence of ownership such as a Certificate of Occupancy and formal documentation of land transactions in public land registries, are essential to the efficient functioning of the land markets. For instance, land titling stimulated land markets in Thailand where titling project increased the number of households engaged in land transaction and in Davao, Jakarta, Indonesia where tenure security such as having a registered title strongly affected land prices (Feder \& Nishio, 1999). Title documents provide confidence to market operators and are important aspects of security of tenure. This can be seen in the example of China in which $\mathrm{Ma}$ et al. (2013) found that Chinese households that consider land certificates important to the protection of land rights make significant investments on agricultural land. Land registration is vital to the security of tenure and security of tenure plays an important role in enhancing investments in land. In particular, access to land with secure tenure is significant to urban housing delivery. This is important to Nigeria as it faces a severe urban housing shortage. The overall housing deficit is estimated at 17 million units as of 2014 (The Nigeria Housing Finance Programme, 2014).

Land registration was introduced in Nigeria by the British Colonial Administration in 1863 (Federal Ministry of Housing and Urban Development, 2006). However, despite this relatively long history of land registration and the importance of land registration to land market operations, the level of land title registration is low (Federal Ministry of Housing and Urban Development, 2006). Estimates indicate that in all of Africa, less than $15 \%$ of the land has been officially registered with title deeds, and for the subSaharan Africa it is just 1\% (Tibaijuka, 2004). However, the reasons behind why registration rarely occurs is where this research emerges. The study conducts empirical investigations into the challenges to land registration in the Nigerian context.

There are studies in Nigeria's land markets which have either investigated land registration or have alluded to it. They include Babatunde et al.'s (2014) research on the activities of land administration machinery in Abuja, and Minna, Olanrele and Agbato's (2014) study which dealt with land rights registration and property development for poverty eradication and slum clearance in Nigeria. Further, Ojo (2014) researched end-users' satisfaction on land title registration process in Akure, Ondo State. In addition, Nuhu (2009) investigated approaches to enhance land titling and registration in the Kongila neighbourhood of Minna, Niger State. Some of these studies found constraints to land registration. Babatunde et al. (2014) and Olanlere and Agbato (2014) found ignorance, high processing costs, delays and lengthy processes, extortion of money by officials, and government insensitivity to be obstacles to land registration. Ojo (2014) found end-users' dissatisfaction as a significant factor that make the title registration process difficult. 
Interestingly, Nuhu (2009) found a high level of compliance with land registration by landowners with $82 \%$ of the 40 respondents having their land registered. Nuhu however questioned whether the land owners had complied with what he called contemporary registration. While these studies assess the land registration processes within Nigerian context none focus on identifying the challenges to land registration in Nigeria. Furthermore, the above studies fail to look at the issue from a holistic perspective, or from the perception of a diverse sample of households, public land administration agencies, and key consultants in Nigerian land transactions such as law firms and estate surveying and valuation firms. There is a clear gap in the literature and as such this research is essential to addressing the lingering problems of land registration in the country.

Existing research on Nigeria's land markets does not interrogate land registration issues with respect to Kaduna State. Land administration in Nigeria is the responsibility of individual states in accordance with the Land Use Act, 1978. The Act vests all land within the territory of each state in the Governor of that state to hold in trust and administer it for the use and benefit of all Nigerians (Section 1, Land Use Act, 1978). Each state prescribes its own system according to its needs. Kaduna State is the second largest state (by population) in northern Nigeria (NPC, 2009). Its capital, Kaduna, was the capital of the defunct Northern Region, the largest of the three regions at independence. It is today regarded as the political capital of the region. Consequently, land tenure rights, especially in urban areas, are issues of significant public concern in the state. The state, therefore, deserves to be covered in land registration studies.

Thus, the study investigates the challenges to land registration in Kaduna State. The objective is to ascertain, through a robust method of mixing quantitative and qualitative studies with a triangulation of results, the land registration programmes in the state, the frequency of land registration, and the factors that constitute challenges to land registration. This is analysed from the perspectives of households, consultants in land transactions, and the Kaduna Geographic Information System (KADGIS) given its responsibility for land administration in the state. Mixed method studies integrate the components of qualitative and quantitative methods and enable a better and fuller understanding of research problems (Creswell, 2014). The mixed method and triangulation of results, therefore, enhance the validity of the results.

\section{The Research Context}

Nigeria is a developing country in the West African sub-region. Kaduna State belongs to its Northwest geopolitical zone. Land markets in the state are dominated by the private sector; especially individuals and households. In Nigeria, rapid urban population growth and city expansion exist amid inefficient urban management, poor urban planning, high poverty rates, weak institutions, inefficient infrastructure and poor governance. These aspects have continually heightened urban land management problems. Access to urban land by low and middle-income households is particularly difficult in 
the state. However, perhaps even more challenging still, is the task of recording land titles due to low land titling and registration. Obtaining a Certificate of Occupancy ( $\mathrm{C}$ of O), which is the formal evidence of land title, involves a costly and lengthy process. The Centre for Affordable Housing Finance in Africa (2016) notes that the process could take upwards of five years. Similarly, the World Bank (2009) states that the costs for formalising land transactions in Nigeria are cumulatively the highest in the world. In addition, Doing Business (2012) ranked Nigeria 180 out of 183 economies in efficiently registering properties. Registration typically comprises 13 procedures, 82 days and $20.8 \%$ of property value (The World Bank, 2012).

Nigeria's Land Use Act, 1978, broadly regulates land administration in the country. The law established two formal land titles; the Statutory Right of Occupancy granted by a State Governor and the Customary Right of Occupancy granted by a Local Government Chairman. The evidence of these titles is a Certificate of Occupancy, commonly referred to as $\mathrm{C}$ of $\mathrm{O}$. The national law that regulates land registration in Nigeria is the Land Registration Act No. 36 of 1924. The law is adapted by the states. Some states have gone further to enact new laws on land registration. In Kaduna State, relevant laws include the Kaduna State Land Registration Law of 1982, the Kaduna Geographic Information Service (KADGIS) Law of 2015 and the Kaduna Land Use Regulations of 2017. The Kaduna Geographic Information Service Law of 2015 established the KADGIS and charged it with the responsibility of the 'management of land matters in the state including all issues relating to title, registration, searches and such other responsibilities' (Section 15(1) Kaduna Geographic Information Law 2015, p.5). The enactment of the two later laws and the establishment of the KADGIS are significant steps in the state's land administration reform. The KADGIS took over the responsibilities of the former Ministry of Land and Survey. On the other hand, the Kaduna Land Use Regulations of 2017 sets general guidelines for land use and administration in the state. It sets out the procedures for obtaining a Right of Occupancy and the processes for applying for the direct allocation of land from the government and different forms of land registration and formalisation programmes.

This section has highlighted the legal framework that guides land registration in Kaduna State as an indication that the research is on a programme that is backed by law. The research investigates the challenges in the implementation of these laws and is therefore significant.

\section{Literature Review}

The review of the literature on land registration primarily in African contexts is presented in this section to highlight the works that have been done, the key findings of these works and the gaps in the literature and then set the current research in context.

Formal definitions and documentation of land rights provide clarity on the ownership of land. Historically, the need for records in land transactions, especially regarding the secure exchange of ownership, has always existed. 
Even within informal settings, parties provided some form of written evidence of transactions. This need for land records eventually motivated formal land registration systems (Hanstad, 1998).

Land registration is often categorised into registration of deeds and registration of titles. The former is a recording of instruments of property transaction, thus providing evidence on successive transfers of land rights, while the latter provides records of the rights and duties an identified entity holds over specified property (Hanstad, 1998; Kanji et al., 2005). Hanstad (1998) notes that the registration of deeds, called 'land recordation' in the United States, developed first and involves registering or recording documents relating to land interests. Such records, held at a public land registry, establish a priority of claims in cases of double selling of a parcel of land. On the other hand, in title registration, the state guarantees all rights shown in the land register (Hanstad, 1998). Kanji et al. (2005) assert that land titling is the strongest legal form that registration of land rights can take. Across and even within countries variations in land registration systems exist. This existence of variations suggests that findings from one context may not be applicable to a different context and so researches in various aspects of land registration should be extended to contexts where they are lacking. This study is therefore necessary as it conducts investigation in a context in which studies on the subject are scarce.

Land registration enhances the security of tenure, encourages investments in land and enables land to perform its economic functions more effectively, such as in its marketability and use as collateral for credit. Many developing countries consider land registration as a high priority in their quest for economic development (Feder \& Nishio, 1999). One intention of providing formal land tenure rights is to provide strong security of tenure, thereby stimulating investment and efficiency of land use (Holden \& Ghebru, 2016). Secure tenure gives confidence to land market operators and land users. It should be promoted as a means of achieving sustainable urban development (UN-Habitat/OHCHR, 2016). Several international financial institutions, notably the World Bank, international donors and national governments, have since recognised the importance of secure tenure in promoting economic development. Consequently, many of these actors have promoted land titling programmes as a means of enhancing tenure security, securing investments, protecting property rights, unifying land markets, improving access to formal credit and reducing poverty (Payne et al., 2009). Based on these perceived benefits, arguments have been advancing over the years in favour of land titling (Kanji et al., 2005). However, there are variations in the outcomes of land registration programmes in different contexts. Given the importance placed on land registration by many developing countries, the support for it by various international agencies and the benefits that could be derived from it, an investigation into the challenges to land registration is necessary. The outcomes of such research will show areas that need to be addressed to reduce the likelihood of programme failure. This study makes contribution to knowledge in this respect. 
In his seminal book, The Mystery of Capital, the Peruvian economist, Hernando de Soto stressed the importance of formalising property ownership. De Soto (2000) suggests that economic emancipation in the third world and former communist countries is possible through titling and documentation of ownership rights. De Soto argues that the poor in these countries do not lack assets, but that they lack the representation of rights to assets by formal titles which enable the assets to perform their economic functions. He subsequently argues that due to the inadequate documentation of rights to these assets, the assets cannot be traded outside the local circles, readily turned into capital or used as collateral for credit. He refers to these assets as 'dead capital'. De Soto (2000) is in effect saying that granting formal titles to the disenfranchised over their land will resuscitate the 'dead capital' in the assets and consequently provide economic empowerment to the poor. He, therefore, advocates for the formalisation of property rights as a way to tackle poverty. De Soto's work has reignited the debate on property formalisation (Benjaminsen et al., 2008; Sjaastad \& Cousins, 2008). The work coupled with the growing international concern for legal framework regarding land ownership in developing countries, has motivated several governments in these countries to engage with land titling programmes and formalisation of land rights with the aid of international development agencies.

Land assets constitute significant capital. What is far less clear, however, is whether land titling resuscitates 'dead capital' (Payne et al., 2009). Lack of formal titles can constrain the marketability of land or the use of land as collateral. However, there are several other factors that exclude low-income groups from the credit market such that even with formal titles, they may still not be able to resuscitate their 'dead capital'. These factors include low household savings and incomes (which limit households' ability to pay the required deposits for loan and make the instalment repayments), inadequate loanable funds, and high interest rates (Nwuba \& Chukwuma-Nwuba, 2018). Moreover, banks and mortgage institutions in Nigeria do not deal with lowincome groups with respect to mortgages (Nwuba \& Chukwuma-Nwuba, 2018). They usually deal with the high-income groups and people with regular and verifiable income. Such people are mostly in the formal sector, but the majority of the poor and low-income groups operate in the informal sector. The lack of regular and verifiable income excludes poorer Nigerians from the credit market. Thus, land titling is not sufficient to invigorate the 'dead capital' in land held by the poor. The credit market needs to be developed in affordable ways before titling can effectively play the expected role of enabling land to be used as collateral. In many contexts that affect the poor, the imperfections of the credit market can result in failure to meet the preconditions for the operation of the market (Deininger \& Feder, 2009). In such situations, the authors argue, expecting large credit-related benefits from land registration programmes may be unrealistic. Similarly, Payne et al. (2009) found from a literature review that the impact of land titling on access to mortgage credit by the poor seems less impressive than the forecasts. Thus, although land titling provides security of tenure and other benefits, it is not sufficient in itself to address poverty or grant the poor access to the credit market as De Soto (2000) claims. Moreover, for titling to provide the expected benefits, the potential constraints to its implementation have to be 
dealt with. As such, this study's focus on challenges to land registration aims to identify these constraints which can limit the success of land registration programmes. The study is therefore relevant.

In Nigeria, some states have implemented land administration reforms which centre on land titling and registration systems. However, these programmes, which essentially focus on urban land, are mostly reforms of the land registration process. Thus, these reforms involve changes from manual to digital processes rather than massive registration programmes. The states implementing these changes include Lagos, Anambra, Kano, Enugu, Kaduna and the Federal Capital Territory Administration. The Federal Lands Department established the Federal Lands Information System (FELIS) to handle registration of lands under the control of the Federal Government across the states of the Federation. In most cases, land registration takes place on request. Thus, the land registration reform programmes are implemented by the federal and state governments, an indication of the importance attached to it in the country. Therefore, investigating the factors which can pose challenges to these programmes (as does this study) is important to land administration in Nigeria.

The land registration process in Nigeria faces various problems. These obstacles often discourage landowners from registering their land. Aluko et al. (2004) note that the procedure for formalising land transactions after purchase of land in Lagos State is cumbersome, bureaucratic, costly and lengthy. Thontteh and Omirin (2015) investigated land registration reforms in Lagos State with the aim of determining the effectiveness of the Electronic Document Management System (EDMS) used in land registration. The findings indicated that the EDMS improved land registration. The reforms resulted in improvement in security of tenure, public confidence in transactions, centralised and consolidated file storage, and a reduction in waiting time for obtaining land information. However, it did not reduce land disputes, or increase the number of applications processed or revenue generation by the government. In addition, it takes over 120 days to process title registration. The problems affecting land registration in the state include: the high cost of registration, inadequate technical skills and incompetent staff, high land charges, ambiguous legal framework and institutional problems (Thontteh \& Omirin, 2015). Although these studies have identified some challenges to land registration, they focus only on Lagos State. This study extends the enquiry on land registration in the Nigerian context to Kaduna State where research on the subject is sparse and as such fills some gaps in the literature.

A number of other African countries have implemented land titling and various other forms of formalisation programmes. Kanji et al. (2005) investigated land titling in Ghana, Mozambique and Ethiopia. They found that land registration systems are different between and within the countries. In Ethiopia and Mozambique, variants of the land title registration model are adopted while in Ghana, deeds registration and land title registration are used. With regard to land registration in the peri-urban areas, the findings indicated that in all the case studies, low-income groups had low access to registration 
systems which tended to encourage the transfer of rights to investors and elites. In Ghana, the process of land registration takes a long time, is cumbersome, and has failed to address the widespread tenure insecurity. The land title registration process is inaccessible to most people and appears not to provide tenure security in the perception of local land users. The study also found that in Mozambique, registration was not accessible to low-income groups due to lack of information and high costs, many of which are illegal payments such as paying officials to process an application. Overall, transparency is vital to an equitable and effective system of registering land and property rights (Kanji et al., 2005). The processes and outcomes of land registration in these countries confirm the existence of variations in different contexts and as such support our argument of the necessity for studies in land registration in various contexts. There are therefore knowledge gaps with respect to contexts in which studies are yet to be conducted. This study fills these gaps within the Nigerian context.

Furthermore, Deininger and Feder (2009) reviewed the literature on the impact of land administration intervention in specific contexts. They found that in situations where overall conditions are favourable, there was substantial evidence of positive tenure security effects of land registration, which manifested in higher levels of investment and less effort to protect land rights. However, evidence of improved access to credit as an outcome of formalisation of land rights was negligible. Deininger and Feder (2009) argue that the nature and realisation of the benefits from land registration depend on the broader socio-economic and governance programmes in additional to the actual nature of governance programmes. The evidence of positive tenure security outcomes from land registration is of economic importance because research has shown that security of tenure has the potential to stimulate investment and efficiency of land use (Holden \& Ghebru, 2016). It is important therefore to find out the challenges to land registration which could constrain its effectiveness and limit the realisation of this important outcome. These studies do not address the subject. That is the essence of this study - to ascertain these challenges in the Nigerian context to enable Nigeria's land administrators plan land registration reforms more effectively.

In addition, Feder and Nishio (1999) reviewed the literature on empirical works on the benefits of land registration. The study provided empirical evidence of the economic benefits of land titling and registration in several countries. These benefits include access to institutional credit, increased investment in land, higher productivity, higher incomes and greater efficiency of the land market (Feder \& Nishio, 1999). Durand-Lasserve and Selod (2007) also provided empirical evidence that tenure formalisation programmes improved land market efficiency, labour market participation, housing conditions, and health and fertility. Interestingly, the review did not find an impact on access to credit. Similarly, an evaluation of the short-term impact of a pilot land regularisation programme in Rwanda found improved access to land for legally married women and a significant impact on investment, which was particularly pronounced for female-headed households (Ali, Deininger, \& Goldstein, 2014). From these studies, there are several economic benefits that result from land registration in various 
contexts. Obtaining these benefits requires that potential obstacles to land registration are addressed. To enable an efficient implementation of land registration programmes by Nigerian states, it is necessary to ascertain what these obstacles are, which is the focus of this study. The outcomes will be beneficial not only to Nigerian states, but also to other African countries due to similarities in the levels of economic development.

In other developing countries beyond Africa, land registration has also gained importance. This is demonstrated in Lawry et al's. (2014) systematic review on the effect of land rights recognition interventions on agricultural productivity, investment and income in Africa, Asia and Latin America through a synthesis of 20 quantitative studies and 9 qualitative studies. The study found substantial productivity and income gains from land tenure recognition but with marked regional variations. It noted that the database for Africa was very limited. The gains were stronger in Asia and Latin America and much weaker in Africa (Lawry et al., 2014). The limited database for Africa suggests the existence of gaps in land registration research within the African context. This study contributes to filling these gaps.

Land registration and titling programmes in some countries have faced challenges and have failed to generate the expected benefits or resulted in negative outcomes as indicated in the reviews that follow. Studies in Mali, Niger and South Africa reveal challenges which could make formalisation counter-productive. These include impending formalisation resulting in a scramble for land in Niger, formalisation playing into the hands of powerful people in Mali and the potential for formalisation to intensify the tension between individual and communal land rights in South Africa (Benjaminsen et al., 2008). Likewise, findings in Dar es Salaam, Tanzania suggest that formalisation of land rights reinforced the relegation of poor urban farmers to the edge of the society, ideologically and physically (Bersaglio \& Kepe, 2013).

Overall, in Sub-Saharan Africa, formal land titling programmes are slow and expensive and central governments lack the capacity to implement fair, largescale national land registration systems (Toulmin, 2009). The result is that in many places simpler versions of land registration involving support to local institutions to implement intermediate forms of registration are more viable options (Toulmin, 2009). In an earlier study of land tenure reforms in Kenya and Tanzania, Pinckney and Kimuyu (1994) found that land titling and tenure reforms did not enable the use of land as collateral for formal sector credit or enhance tenure security, and so the programmes did not provide additional incentive to invest in land. The findings also indicated that land titling in Kenya caused more problems than it resolved resulting in the local communities ignoring the titles and reverting to indigenous tenure (Pinckney \& Kimuyi, 1994)

In addition, through a literature review and case studies in Senegal and South Africa, Payne et al. (2009) found that overall, land titling programmes have failed to achieve their economic or social policy objectives such as enabling access to formal credit, stimulating investments in housing and property 
development, and generating considerable increases in property values. The study found considerable evidence of increased tenure security from land titling. The researchers argue, however, that many alternative forms of tenure including informal or unauthorised settlements also provide high levels of security. Holden and Ghebru's (2016) review of the literature reveals cases of corrupt and inefficient bureaucracies and high costs of formal land titling in different countries. This was reported to result in the displacement of the poor and vulnerable groups in favour of the rich, and an absence of significant investment or credit effects of land titling.

The above cases which indicate both successes and failures in land registration outcomes in different contexts buttress the need for a holistic investigation of the challenges which can constrain land registration programmes from fulfilling their goals. This is where this research emerges as it investigates the problem from the perspective of various stakeholders in the Nigerian context.

In the past two decades, research and policy attention on land registration in Africa have experienced significant growth. Indications from the literature are that many countries have implemented various forms of land registration. Several studies have investigated these land registration programmes through surveys and literature reviews. Most of these studies have researched the benefits and outcomes of land registration programmes. These outcomes vary in different contexts, making research in different contexts necessary. Moreover, although a few existing studies discuss challenges and obstacles to land registration, none is actually designed purposely to investigate the problem in the Nigerian context. This leaves important gaps in the literature. Drawing on a survey of households triangulated with the perspectives of consulting firms in land transactions and the government, this study addresses these gaps within the Nigerian context using a mixed method of surveys and interviews.

\section{Materials and Methods}

The research is a mixed method with a triangulation of results. It combines a quantitative study of a cross-sectional survey with qualitative method involving personal interviews. Two samples were developed for the quantitative study from 326 surveys completed by landowning households, and 53 completed by consultants in land transactions (34 firms of estate surveyors and valuers and 19 law firms). For the qualitative study, 2 samples were developed, one from the government and the other from consultants in land transactions. The government sample comprises two officials and one retired official of KADGIS. The consultants' sample includes 9 respondents (5 estate surveyors and valuers and 4 lawyers). The respondents for the qualitative study were selected through purposive sampling based on their experiences in the subject of investigation. To eliminate a level of bias, the respondents were assured of anonymity.

The rationale for adopting this research design is two-fold. The first reason is to enable the collection of data from a population dispersed in a wide 
geographical area. The survey addressed this issue. The second reason is to get a deeper understanding of the factors that constitute challenges to land registration and the ways they constrain registration. The interviews were used to address this. Interviews provide an opportunity for an in-depth probe into a research question. The mixing of the two methods and triangulation provided greater validity for the results.

In the survey of the consultants, 62 firms of registered estate surveyors and valuers who practice property transaction consultancy, were identified through the Kaduna State Branch of the Nigerian Institution of Estate Surveyors and Valuers (NIESV). All the firms were surveyed. In addition, 53 law firms were identified through the local chapter of the Nigerian Bar Association. 19 firms that practice property transaction consultancy were surveyed. A total of 53 questionnaires were retrieved, comprising 34 for estate surveyors and valuers and 19 for law firms. That translates to a response rate of $65 \%$.

The household survey was for a more extensive study. The sample was drawn from an estimated population of 705,322 regular urban households in Kaduna State. A regular household refers to a household consisting of,

"a person or group of persons living together usually under the same roof or in the same building/compound, who share the same source of food and recognise themselves as a social unit with a head of household"

(NPC, 2010, p.iii)

The National Population Commission usually measures its housing distributions such as housing tenure with regular households. In the 2006 national census, regular household population in Kaduna State was 1,115,974. (NPC, 2010). This figure was updated to 2016 with the national annual average population growth rate of $2.65 \%$ for $2005-2010$ and $2.67 \%$ for 2010 - 2015 (United Nations, Department of Economic and Social Affairs, Population Division, 2015). The study population was then estimated from the updated figure of $1,451,280$ households at $48.6 \%$, the country's estimated proportion of urban population to the total in 2016 (United Nations, Department of Economic and Social Affairs, Population Division, 2014). Thereafter, the sample size was determined with the Taro Yamane sample size formula which is given as:

$$
n=\frac{N}{1+N(\mathrm{e})^{2}}
$$

Where $n=$ sample size required

$\mathrm{N}=$ the population size

$\mathrm{e}=$ the level of precision

(Singh \& Masuku, 2014)

Thus, the sample size for the estimated population of 705,322 households at a precision level of $\pm 5 \%$ is approximately 400 . A sample of 450 households was surveyed. However, this paper is on an aspect of the survey which 
covered 326 landowning households who either inherited their land or purchased from private landowners.

The survey employed a stratified two-stage cluster sampling scheme. The population was stratified into three based on the senatorial districts in the state. Kaduna city was surveyed in the Kaduna Central Senatorial District. Zaria was surveyed in Kaduna North. Moreover, Kafanchan and Zonkwa were surveyed in Kaduna South. Cluster sampling was then employed with the wards in each city as clusters. Households were then subsampled in the wards through a random process.

Questionnaires designed for the study were used to collect the data. Households were required to state whether they registered their land titles and transactions with the land registry (a sample of the questionnaire is attached as an appendix). On the other hand, the consulting firms were required to state how often they register their clients' titles and transactions on a 7-point scale ranging from 7 for always, 4 for only sometimes, and 1 for never. Both samples were also asked the challenges they encountered in the process of registration and the reasons for non-registration. The survey results were triangulated with interviews of state officials and professionals. The triangulation enabled cross-validation of the results.

The questionnaires were validated on a random sample of 50 households and 5 consultants with Kendall's coefficient of concordance (W). The reliability was measured with the Cronbach's alpha statistic. The interviews were oneon-one and were semi-structured. An interview guide was prepared and piloted on one respondent. Based on the observations, the guide was modified, and a final version prepared and used in the study. The interviews were conducted in December 2017, January 2018 and April 2018 and with the consent of the interviewees, recorded on electronic devices. The survey data analysis employed frequency, percentages and mean, while the interview data were transcribed and analysed with the thematic analysis method.

\section{Results}

\subsection{Respondents' Demographic Characteristics}

Table 1 contains the households' demographic characteristics. Male respondents comprise $81.3 \%$, while female respondents constitute $18.7 \%$. The majority, comprising $81.6 \%$ are married while only $18.4 \%$ are single. The age bracket of 40 to 49 constitute $35.6 \%$ of respondents and is the largest proportion. About $67.5 \%$ of the respondents have a degree or other tertiary education. Mean sample household monthly income is 77,312 Naira (US\$212.60), while the median is 73,500 Naira (US\$202.13). Mean household size is 7.06 , while the median is 6 . About $75.5 \%$ of the respondents acquired their land through purchase from private landowners while $24.5 \%$ acquired through inheritance. Overall, the sample has a sufficient spread of respondents over different categories of households. 
Table 1: Households' Demographic Characteristics

\begin{tabular}{l|ccc} 
Characteristics & Frequency & Percent & Cum percent \\
\hline Sex & & & \\
\hline Male & 265 & 81.3 & 81.3 \\
Female & 61 & 18.7 & 100.0 \\
Marital Status & & & \\
\hline Married & 266 & 81.6 & 81.6 \\
Single & 60 & 18.4 & 100.0 \\
Age bracket of respondent (years) & & & \\
\hline Less than 30 & 42 & 12.9 & 12.9 \\
$30-39$ & 108 & 33.2 & 46.1 \\
$40-49$ & 113 & 34.5 & 80.6 \\
50 and above & 63 & 19.4 & 100.0 \\
Educational level of respondent & & & \\
\hline No formal education & 1 & 0.5 & 0.5 \\
Primary education & 11 & 3.5 & 4.0 \\
Secondary education & 93 & 28.5 & 32.5 \\
Degree/other tertiary education & 220 & 67.5 & 100.0 \\
Source of land acquisition & & & \\
\hline Purchase from private landowners & 246 & 75.5 & 75.5 \\
Inheritance from family/communal land & 80 & 24.5 & 100.0 \\
\hline
\end{tabular}
Source: Field Survey, 2017.

Tables 2 and 3 contain the demographic characteristics of the estate surveying and valuation firms and law firms respectively. In each case, the largest proportion of the firms has a staff strength of 6 to 10. Among the estate surveying firms, $47 \%$ has rendered services in property transactions for 6 to 10 years, while among law firms, the majority of $57.9 \%$ has rendered services for 15 to 20 years. Male respondents constitute the majority in both samples. All the responding lawyers are married, while $85.3 \%$ of the estate surveyors are married. Furthermore, $58.8 \%$ of the estate surveyors had experience of 10 years or less, while $41.2 \%$ had over 10 years' experience. For the lawyers, $47.4 \%$ had experience of 10 years or less, while $52.6 \%$ had over 10 years' experience. The age bracket of 40 to 49 constitutes the highest proportion of respondents in both cases. Also, a majority of the respondents hold a Bachelor's degree. The sample reflects the situation in the market. Most practice owners or heads in the two professions are middle-aged, married men who possess a first or Master's degree or a higher national diploma for estate surveyors and valuers. 
Table 2: Respondents' Demographic Characteristics (Estate Surveying and Valuation Firms)

\begin{tabular}{|c|c|c|c|c|}
\hline Characteristics & Response Categories & Frequency & Percent & Cumulative percent \\
\hline \multirow[t]{5}{*}{ Firm's staff strength } & $1-5$ & 12 & 35.3 & 35.3 \\
\hline & $6-10$ & 14 & 41.2 & 76.5 \\
\hline & $11-15$ & 2 & 5.9 & 82.4 \\
\hline & $16-20$ & 4 & 11.8 & 94.1 \\
\hline & Above 20 & 2 & 5.9 & 100.0 \\
\hline \multirow{5}{*}{$\begin{array}{l}\text { No. of years firm has rendered service in land } \\
\text { agency in Kaduna }\end{array}$} & $1-5$ & 2 & 5.9 & 5.9 \\
\hline & $6-10$ & 16 & 47.1 & 53.0 \\
\hline & $11-15$ & 7 & 20.6 & 76.6 \\
\hline & $16-20$ & 3 & 8.8 & 82.4 \\
\hline & Above 20 & 6 & 17.6 & 100.0 \\
\hline \multirow[t]{2}{*}{ Responding officer's sex } & Male & 32 & 94.1 & 94.1 \\
\hline & Female & 2 & 5.9 & 100.0 \\
\hline \multirow[t]{2}{*}{ Responding officer's marital status } & Married & 29 & 85.3 & 85.3 \\
\hline & Single & 5 & 14.7 & 100.0 \\
\hline \multirow[t]{4}{*}{ Responding officer's age group } & Below 30 & 2 & 5.9 & \\
\hline & $30-39$ & 10 & 29.4 & 5.9 \\
\hline & $40-49$ & 19 & 55.9 & 39.3 \\
\hline & 50 and above & 3 & 8.8 & $\begin{array}{c}91.2 \\
100.0\end{array}$ \\
\hline \multirow{5}{*}{$\begin{array}{l}\text { Responding officer's post-qualification } \\
\text { experience (years) }\end{array}$} & $1-5$ & 4 & 11.8 & 11.8 \\
\hline & $6-10$ & 16 & 47.1 & 58.8 \\
\hline & $11-15$ & 10 & 29.4 & 88.2 \\
\hline & $16-20$ & 1 & 2.9 & 91.2 \\
\hline & Above 20 & 3 & 8.8 & 100.0 \\
\hline \multirow[t]{4}{*}{ Educational qualification } & $\mathrm{PhD}$ & 1 & 2.9 & 2.9 \\
\hline & Master's degree & 9 & 26.5 & 29.4 \\
\hline & Bachelor's degree & 10 & 29.4 & 58.8 \\
\hline & HND & 14 & 41.2 & 100.0 \\
\hline
\end{tabular}

Source: Authors' Field Survey, 2017 
Table 3: Respondents' Demographic Characteristics (Law firms)

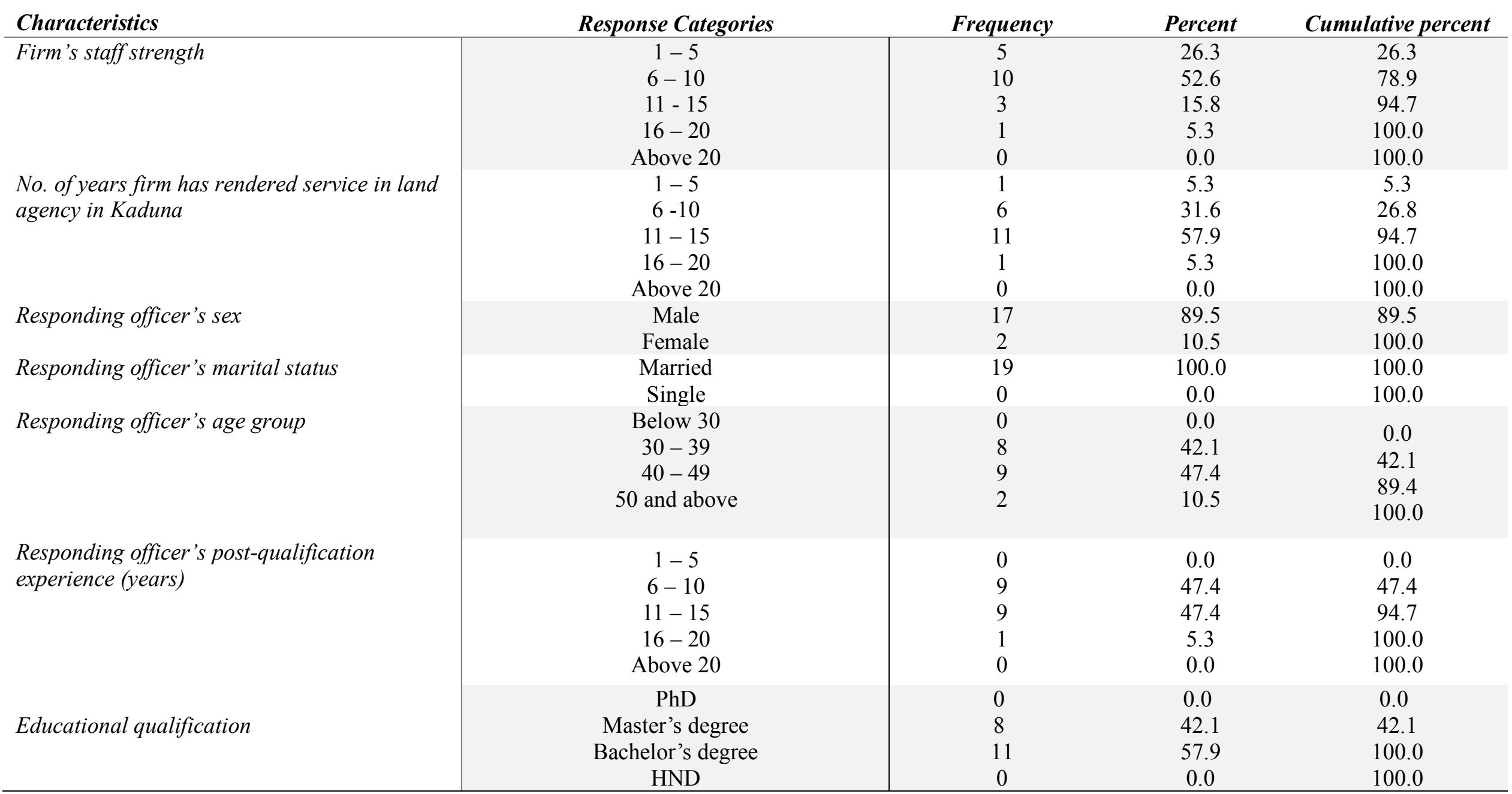

Source: Authors' Field Survey, 2017. 
Table 4 contains the demographic characteristics of the interview respondents of which nine are male and three are female.

Table 4: Interview Respondents' Demographic Characteristics

\begin{tabular}{|c|c|c|c|c|c|c|c|}
\hline Resp.ID & Sex & $\begin{array}{l}\text { Age } \\
\text { Bracket }\end{array}$ & $\begin{array}{l}\text { Marital } \\
\text { Status }\end{array}$ & $\begin{array}{l}\text { Educational } \\
\text { Qualification }\end{array}$ & Profession & $\begin{array}{l}\text { Experience } \\
\text { (in years) }\end{array}$ & Remarks \\
\hline M01SS & Male & $41-45$ & Married & HND & ESV & 17 & State official \\
\hline M02L & Male & $36-40$ & Single & LLB, BL & LAW & 7 & $\begin{array}{l}\text { Private } \\
\text { practitioner }\end{array}$ \\
\hline M03ES & Male & $46-50$ & Married & M.Sc. & ESV & 15 & $\begin{array}{l}\text { Private } \\
\text { practitioner }\end{array}$ \\
\hline M04ES & Male & $46-50$ & Married & HND & ESV & 7 & $\begin{array}{l}\text { Private } \\
\text { practitioner }\end{array}$ \\
\hline M05SS & Male & $51-55$ & Married & B.Sc. & Geography & 10 & State official \\
\hline M06ES & Male & $41-45$ & Married & $\mathrm{PhD}$ & ESV & 13 & $\begin{array}{l}\text { Private } \\
\text { practitioner }\end{array}$ \\
\hline M07ES & Male & $46-50$ & Married & M.Sc. & ESV & 15 & $\begin{array}{l}\text { Private } \\
\text { practitioner }\end{array}$ \\
\hline M08ES & Male & $51-55$ & Married & HND & ESV & 9 & $\begin{array}{l}\text { Private } \\
\text { practitioner }\end{array}$ \\
\hline M09SS & Male & $55-60$ & Married & HND & ESV & 38 & $\begin{array}{l}\text { Retired state } \\
\text { official }\end{array}$ \\
\hline F10L & Female & $36-40$ & Married & LLB, BL & Law & 7 & $\begin{array}{l}\text { Private } \\
\text { practitioner }\end{array}$ \\
\hline M11L & Male & $51-55$ & Married & LLB, BL & Law & 20 & $\begin{array}{l}\text { Private } \\
\text { practitioner }\end{array}$ \\
\hline F12L & Female & $46-50$ & Married & LLB, BL & Law & 15 & $\begin{array}{l}\text { Private } \\
\text { practitioner }\end{array}$ \\
\hline
\end{tabular}

Source: Authors' field work, 2017 and 2018

Notes:

1. $\quad \mathrm{ESV}=$ Estate surveyor and valuers.

2. Experience refers to post professional registration for the ESV, post call to bar for the lawyers and years in public service for state officials.

3. ESVs usually work for a considerable period, sometimes up to 10 years after academic qualification before they get professionally registered. Thus, total work experience is usually much longer than post-professional registration experience.

4. Retired state official (35 years of public service, 3 years of private practice).

\subsection{Quantitative Results}

The results in Table 5 indicate that the majority of landowners who purchase or inherit their land do not register their land. Over $70 \%$ of respondents did not register. Interestingly, a majority of this group, about $65 \%$, do not consider registration necessary and the remaining 35\% do not know about registration. The respondents are either not aware of registration, or they are aware but do not consider it necessary. In either case, it is a problem of ignorance. The results therefore demonstrate that ignorance is a significant 
constraint to land registration in Kaduna State. A noteworthy minority of respondents, 29\%, registered. Respondents who registered their land experienced problems, the most significant being the long process of the registration. Over $87 \%$ of the respondents who registered their land encountered this problem. Also, a substantial proportion of respondents who registered, constituting 75\%, encountered high costs, while about $67 \%$ experienced delays.

\section{Table 5: Summary statistics on the frequency of land registration and registration constraints (Households' data)}

\begin{tabular}{l|ccc}
\multicolumn{1}{l}{$\begin{array}{l}\text { Variable } \\
\text { Method of land acquisition }\end{array}$} & Percent & $\begin{array}{c}\text { Cumulative } \\
\text { percent }\end{array}$ \\
\hline If you have land or building, how did you acquire & & & \\
the land? & 14 & 3.9 & 3.9 \\
Direct state government allocation & 22 & 6.1 & 10.0 \\
Direct local government allocation & 246 & 68.0 & 78.0 \\
Purchase from private landowners & 80 & 22.0 & 100.0 \\
Inheritance from family/community land & & & \\
\hline Frequency of registration & & & \\
\hline If you purchased or inherited your land, did you & 96 & 29.4 & 29.4 \\
register your land with the Lands Ministry? & 230 & 70.6 & 100.0 \\
Yes & & & \\
No & 72 & 75.0 & N/A \\
\hline If you registered your land, what challenges did & 84 & 87.5 & N/A \\
you encounter in the process & 64 & 66.7 & N/A \\
High cost of the registration & & & \\
Long process & & & \\
Delays & 150 & 65.2 & 65.2 \\
& 80 & 34.8 & 100.0 \\
\hline If you did not register your land, what was the & & & \\
main reason? & & \\
Don't think registration is necessary & & \\
Don't know about registration & & \\
\hline
\end{tabular}

Source: Field Survey, 2017.

From the consultants' results (Table 6), registration is carried out 'Only sometimes' which recorded the highest response of $41.5 \%$. The mean for the construct on the 7-point scale is 4.11 which falls within 'Only sometimes'. This is fairly high compared to households' results which suggests that land purchasers are more likely to register their land if consultants handle the transactions. Nevertheless, the level of registration is still low for urban land markets. About $24.5 \%$ of the respondents say they often or always carry out registration. In contrast, a higher proportion comprising about $34 \%$ say they rarely or never carry out registration. The results therefore demonstrate a low level of land registration in the study area, which corroborates the households' results. 
The most significant reason for non-registration is high cost - 'client says registration is expensive'- was experienced by $54.7 \%$ of the respondents. The next is 'client does not ask me to register' which recorded a $28.3 \%$ response rate. This factor suggests that the client is either not aware of the necessity to register or does not want to register. The main challenges encountered in the process of registration are delays and lengthy processes, which were experienced by $81 \%$ and $77.4 \%$ of the respondents respectively. About $28.3 \%$ of the respondents respectively experienced high cost and making unofficial payments to officials. Making unofficial payments is a strong indication of corrupt practices.

\section{Table 6: Summary Statistics of the frequency of land registration and registration constraints (Consultants' Data)}

\begin{tabular}{l|ccc}
\multicolumn{2}{l}{$\begin{array}{l}\text { Variable } \\
\text { When you purchase residential land for your }\end{array}$} & Percent & Cumulative percent \\
$\begin{array}{l}\text { clients, how often do you register the } \\
\text { transaction/your client's title with the lands registry }\end{array}$ & & & \\
& & & \\
\hline Always & 6 & 11.3 & 11.3 \\
Very often & 4 & 7.5 & 18.9 \\
Often & 3 & 5.7 & 24.5 \\
Only sometimes & 22 & 41.5 & 66.0 \\
Rarely & 14 & 26.4 & 92.5 \\
Very rarely & 3 & 5.7 & 98.1 \\
Not at all & 1 & 1.9 & 100.0 \\
\hline In cases that you registered titles/transactions, what & & & \\
problems did you encounter in the process? & & & \\
& & & \\
\hline High cost for the registration & 15 & 28.3 & N/A \\
Long process & 41 & 77.4 & N/A \\
Delays & 43 & 81.1 & N/A \\
Making unofficial payments to officers & 15 & 28.3 & N/A \\
Others (please specify) & 0 & 0.0 & \\
\hline In cases that you did not register your transactions & & & \\
with the lands registry, what was the main reason? & & & \\
& & & \\
\hline Client does not ask me to register & 15 & 28.3 & \\
Client says registration is expensive & 29 & 54.7 & \\
Client says registration is not necessary & 3 & 5.7 & \\
I do not discuss registration with the client & 6 & 11.3 & \\
\hline & & & \\
\hline
\end{tabular}

Source: Field Survey, 2017. 
Integrating the results of the two samples, the findings indicate that the level of land registration is low and that the following are challenges to land registration:

Ignorance on the part of landowners, high costs for registration, lengthy process, and delays in processing registration.

\subsection{Qualitative Results}

This section presents the results from the qualitative aspect of the study. The results are presented and discussed in themes which emerged from the analysis of the interviews conducted in the study. The themes are Land Registration Programmes and Processes, Reasons for Non-registration of Land and Challenges in the Registration Process. These themes enable the understanding of land registration issues in Nigeria with greater depth and in context. Table 7 contains the themes and the variables (sub-themes) for each theme).

\subsubsection{Land Registration Programmes and Processes}

The state officials identified and explained 6 land registration programmes in the state as shown in Table 7. Explanations of each programme and their procedures as provided by the government officials are included below.

Table 7: Thematic Analysis Results

\begin{tabular}{|c|c|c|}
\hline$S / N$ & Themes & Variables \\
\hline 1 & $\begin{array}{l}\text { Land Registration Programmes } \\
\text { and Processes }\end{array}$ & $\begin{array}{l}\text { Systematic Property Registration Programme } \\
\text { Systematic Recertification Programme } \\
\text { Systematic Regularisation Programme } \\
\text { Regular Application (Clean grant) } \\
\text { Direct Allocation (Title registration) } \\
\text { Deeds Registration }\end{array}$ \\
\hline 2 & $\begin{array}{l}\text { Reasons for Non-registration of } \\
\text { Land }\end{array}$ & $\begin{array}{l}\text { Ignorance } \\
\text { Attitude } \\
\text { Affordability problem } \\
\text { Registration process } \\
\text { Ownership type } \\
\text { Avoiding payments to government } \\
\text { Perceived security of tenure }\end{array}$ \\
\hline 3 & $\begin{array}{l}\text { Challenges in the Registration } \\
\text { Process }\end{array}$ & $\begin{array}{l}\text { Corruption } \\
\text { Inefficient Process - manifests in: } \\
\text { - Poor Record-keeping } \\
\text { - Delays } \\
\text { - Lengthy processes } \\
\text { - Cumbersome process } \\
\text { Inadequate human capital and working tools } \\
\text { Incomplete documentation by applicants } \\
\text { Resistance to change by government staff }\end{array}$ \\
\hline
\end{tabular}

Source: Authors' interviews 2017/2018 


\section{1) Systematic Property Registration Programme}

Systematic property registration is targeted at low and middle-income earners who have houses but do not have the means to process $\mathrm{C}$ of $\mathrm{O}$ (M01SS). It aims to title all occupants of land within high density urban and rural areas and agricultural land. It is a process of mass land registration with the government taking the initiative and covering the costs. KADGIS officials go house to house to get the details of properties and their owners. The agency then compiles a list of landowners and after public display sends the list to the governor for approval. The landowners are issued $\mathrm{C}$ of $\mathrm{O}$ at a token fee of 5,000 Naira (US\$13.8). About 5,000 certificates have been issued through this programme (M01SS)

\section{2) Systematic Recertification Programme}

Recertification is a mandatory conversion of the old manual certificates of occupancy to digital form. The process requires holders of statutory or customary right of occupancy to submit a recertification application form to KADGIS. The applicant submits the old $\mathrm{C}$ of $\mathrm{O}$ to KADGIS for cancellation and issuance of a new digital certificate. The old certificate is properly vetted because we have instances of people submitting fake certificates (M01SS). The programme is a reform to curtail fraudulent acts in title documents and restore confidence in land transactions (M09SS). The state officials say the process takes 30 days, but the consultants interviewed dispute this, saying it takes several months and even years. The agency continually overshoots its time targets. The processing fees are graduated with time. At the beginning of January 2017 , it was 20,000 Naira (US $\$ 55$ ). It has increased by 10,000 Naira every quarter to 40,000 Naira. There is an additional fee of 20,000 Naira for the registration of $\mathrm{C}$ of $\mathrm{O}$. If the recertification requires assignment, the applicant pays an additional fee of 80,000 Naira (US\$220) Fees for assignment were previously $6 \%$ of the capital value of the property (M01SS).

Previously, holders of Customary Right of Occupancy converted them to the Statutory Right of Occupancy under a registration programme called Conversion. This process involves changing a customary right of occupancy granted by a local government to a statutory right of occupancy granted by the governor of a state (M009SS). This became necessary because areas where local governments prepared layouts and made grants were declared urban areas and since it is only the Governor that can grant right of occupancy in urban areas, holders of customary rights of occupancy issued by local governments are required to change their rights to statutory rights (M09SS).

\section{3) Systematic Regularisation Programme}

This land registration programme entails formalising planned, unapproved layouts and property rights in them. Occupants of such layouts are required to apply to the state government to regularise their land rights, but the programme is yet to commence. The layout has first to be reviewed for conformity with planning regulations (M01SS). Unapproved layouts are created without state government approval. They are usually created by 
private landholders who subdivide their land and sell to individuals to develop.

\section{4) Regular Application}

The regular application is a process in which a landholder, who has never held a right of occupancy on any land he or she occupies or claims, applies for a new grant for the right of occupancy through the Regular application process. It covers registration previously done under a programme termed, Clean Grant, which is the formalisation of titles obtained from the purchase of land from customary landholders. "The process starts from the zonal lands office" (M09SS). It requires the applicant to provide two key documents as evidence of title - the sale agreement and confirmation of the title of the applicant by the district head, the village head and the ward head of the area where the land is located (M09SS). These are the customary land administrators, and their confirmation of title is required "to curb land disputes and problems that sometimes arise due to conflicts of ownership" (M09SS). The application is lodged at the zonal land office in the local government. The Zonal Land Officer sends the application to the Chairman of the Local Government for recommendation and after the recommendation sends it to the headquarters of the KADGIS for title processing (M09SS).

\section{5) Direct Allocation}

Registration under this programme involves registering title documents that result from government allocation of land. The government prepares layouts and allocates the plots to applicants. It issues rights of occupancy to the allotted owners, who are required to pay the fees for the processing of title (M01SS; M05SS). Survey plans are prepared for each of the plots by the state Surveyor-General, and a $C$ of $O$ is prepared in the name of each allottee and executed by the governor. Thereafter, the allottee pays the full allocation and processing fees before the document is registered by the deeds register and the $C$ of $O$ delivered to the title holder. There have not been direct allocations recently (M01SS; M05SS).

\section{6) Deeds Registration}

This is the registration of transactions such as mortgages and assignments of land rights. The Land Use Act of 1978 requires that the consent of the Governor be obtained for all alienation of land rights. The governor's approval specifies the conditions for granting the consent. For assignments, if there is a transaction and the parties want the formal transfer of title to the new owners, the title holder will make an application for title transfer by assignment. When the consent of the governor is obtained, the deed of assignment is stamped and registered, and a change of ownership takes place. After the registration of the deed of assignment, a certificate of occupancy is processed and issued in the name of the assignee. However, from the time the deed of assignment is registered, the title is conferred on the assignee (M09SS). 
The period for processing applications varies with types. The state officials explained that assignments usually take one month, while consent to mortgage takes about one week from the time the application is submitted and all documentation provided. The other registration programmes take one to two months from the time application is submitted at the agency's office with all documentation provided (M09SS).

\subsubsection{Reasons for Non-Registration}

As shown in Table 7, the interviewees advanced a number of reasons why landowners do not register their land, which include ignorance, nonchalant attitudes to registration by landowners, affordability problems, perceived security of tenure, and communal ownership of land. These findings corroborate the survey results. The impact, according to the interviewees, is that the level of registration is low which also confirms the survey findings. All the respondents agree that ignorance is a major hindrance to land registration. They say there is a general lack of awareness about registration. A respondent stated: "People practically do not know the value attachment to documentation of land transactions" (M02L). Similarly, another respondent stated: "A lot of them don't even see the reason why they should obtain title to their land... Some believe that it is only when they want to sell or take a loan from the bank that they need registration" (M03ES). The respondents also believe that landowners have a nonchalant attitude towards registration.

In addition, most of the respondents agreed that affordability is a major problem. They say the costs are too high relative to the income of the people, despite cost reductions the government has introduced. As a respondent stated:

"A lot of them cannot afford the cost of registering their title. The government put a flat cost of 80,000 Naira. A lot of people are still poor... In many suburbs, the cost of land is about 300,000 Naira and you are asking them to pay about 25\% of that [for registration]"

(M03ES)

He argues that the government should still reduce the costs. However, another respondent has a different view. Although he agreed that cost is a problem, he said that the problem is more of attitude than costs. He stated: "One thing I want to believe is that it is not money. The money they pay for the certificate is nothing compared to the amount they purchase the property" (M02L). The government appears to have recognised the affordability problems and introduced cost reductions for the different registration programmes and the officials believe that government has done much in cost reduction. They cited an example of a deed of assignment, which used to cost $6 \%$ of the value of the property but is now fixed at a flat rate of 80,000 Naira (M09SS). A consultant agreed to this (M11L)

Other reasons why landowners do not register their land include ownership type, perceived security of tenure under the customary land tenure system, delays and lengthy process of registration and attempts to avoid paying government charges such as ground rents, which landowners pay when their titles are registered. The respondents say that people do not usually register 
land that is communally owned such as family land because the co-owners do not normally agree as to whose name should be used for the registration (M07ES). The government has recently tried to solve this problem by registering communally-owned land under the programme termed Systematic Land Title Registration (SLATR), now called Systematic Property Registration Programme. (SPRP) (M07ES; M11L). The respondents could not however confirm the success of the programme. In addition, the delays in processing registration and the lengthy registration process discourage landowners from registering their land (M07ES). Furthermore, as the respondents point out, customary landowners who are natives in an area perceive that the traditional institutions offer them secure tenure and so they do not need registration. They see registration as an exercise for people who are not natives of the area (commonly referred to in Nigeria as non-indigenes) who purchase land from them (M03ES). Across the country, customary land tenure offers security of tenure as the state recognises titles held under native law and custom. The only issue with such titles is the inability to use them for formal transactions such as collateral.

\subsubsection{Challenges in the Registration Process}

The results also indicate that there are various challenges in the land registration process (Table 7). They include corruption of public officers, the inefficiency of the registration process, inadequate human capital, resistance to change by the officers, and incomplete documentation by applicants.

The respondents consider corrupt practices a critical challenge, especially before the introduction of reforms (M06ES; M02L; M11L). Making unofficial payments to land registry officials can make a difference in the service delivery by substantially reducing the processing time. The results showed that officials posed as consultants such that it became customary for people who came to register land to engage them for a fee to 'follow up' on their files. Speaking about the previous system, a respondent stated,

"The speed of the procedure depends on who is following it up and how much you are able to give outside the official fees... no official time frame. It depends on what you can do and your relationship. The relationship and some tips were the major factors"

(M06ES)

Other respondents corroborate this response. As a state official stated: "Some of the staff paraded themselves as consultants" (M05SS). Another respondent described it thus:

"In the previous system, land registration had always been who you have to assist you to push for what you want... you have to have unofficial retainership with some identified staff who have a kind of inroad into the system to facilitate it... But with the introduction of KADGIS, the process has been simplified... is very straightforward. With or without knowing anybody in KADGIS, your processing will go on smoothly" (M04ES) 
These are manifestations of corrupt practices which is in agreement with the survey finding of making unofficial payments to officials.

The results also indicate that the system is inefficient. The inefficiency manifests in record-keeping problems, delays in the processing of registration applications, and lengthy and cumbersome processes. These findings are consistent with those from the surveys. Describing the situation, a respondent stated:

"I have up to 60 files [applications] for recertification. There are certain payments I made February last year for recertification. And now it is April current year. A state government engaged me to perfect their title documents for all their land, but up till now, there is nothing. They have not been able to process even one single application. I have written up to ten reminders to the DG KADGIS, but unfortunately, there is no response... You go to their complaint desk, they will say they will get back to you, but they will not."

(M11L)

The respondents say the registration process is lengthy and cumbersome and involves many delays. They identified inefficiency, record-keeping problems, the powers of the governor under the law to grant rights of occupancy and the requirement for the consent of the Governor for alienation of land as the major causes of the delays and lengthy process (M11L; F12L). The Governor signs the certificates of occupancy and approves grants and consents. The process often results in delays due to the busy schedule of the governor. Respondent M11L stated that he has tried to process some applications for the past two years without success. The record-keeping is a widespread complaint. As a respondent described it:

"...you can go several times [to the land registry] without laying your hand on the file. There won't be record to show which office the file is... There is a particular one that took me almost six months to lay my hands on the file"

Another respondent stated: "It takes a long time for the files to be found...A times, the files are misplaced, or they cannot be found" (F10L). A state official said that inadequate facilities for file storage caused the problem. He stated: "We experienced a lot of missing files" (M09SS). The state officials identified a shortage of qualified manpower, people's resistance to change, and incomplete documentation by applicants as challenges the agency faces. As one official stated:

"We have issues of people refusing to accept change... we have staff that are really not ready to key into the changes. Even on the part of the public, we have that challenge... because people think they can do things the old way. But the most important challenge is a shortage of qualified manpower"

(M01SS)

They said that these factors are some of the causes of delays. They also said that when there is incomplete documentation, the processing of an application is put on hold (M05SS; M09SS). 
Thus, the results have shown that there are a number of factors that constrain land registration. The respondents are unanimous in indicating some measures which should be taken to minimise these challenges. They include creating awareness through public enlightenment programmes, further cost reductions, engagement of more staff with the relevant skills, and creating a more efficient processing system.

\subsection{Integrating Quantitative and Qualitative Results}

Integrating the results from the qualitative and quantitative studies, we can summarise the findings as follows:

The Kaduna State government has 6 different programmes for registration of land. These are: (1) the Systematic Property Registration Programme, (2) the Systematic Recertification Programme, (3) the Systematic Regularisation Programme, (4) the Regular Application, (5) the Direct Allocation, and (6) the Deeds Registration.

The level of land registration in the state is low. In addition, there are a number of challenges to land registration, some of which are reasons why landowners do not register their land while others are challenges encountered in the registration process. The reasons why landowners do not register their land include: ignorance on the part of landowners, inability of landowners to afford the cost of registration, nonchalant attitude to land registration by landowners, communal ownership of land, attempts by landowners to avoid paying government charges such as ground rents, perceived security of tenure under the customary land tenure, and the delays and lengthy process of registration which discourage people.

Similarly, factors which constitute challenges in the land registration process include corruption (which manifests in making unofficial payments to land registration officials), and inefficient registration process (which manifests in poor record-keeping, delays, and lengthy and cumbersome processes). Other factors include: inadequate human capital and working tools, resistance to change by KADGIS officials, and incomplete documentation by applicants. All these factors, in one way or the other, limit land registration, resulting in low level of registration

\section{Discussion of Results}

The results of the quantitative and qualitative studies corroborate each other. Both suggest the existence of failures in the land administration system, which cause failures in the land market and consequently market inefficiency. Despite the various land registration programmes, the level of registration is low which suggests that the system is inefficient. A low level of land registration means that official records do not capture the majority of land transactions in the state. This has an implication for government revenue and the availability of information for land market transactions. The government loses revenue it would otherwise get if the level of registration were high. This suggests that there is room for increase in land-based revenue in the state. 
Moreover, the low level of registration means that often market participants do not get adequate information for their transaction. Scarcity of information causes market failure, resulting in the land market being inefficient. The situation is exacerbated by the numerous challenges to land registration. There is, therefore, a need for the government to vigorously pursue the reforms it has introduced within the land administration system.

The findings on the factors that constitute challenges to land registration support Babatunde, et al. (2014), Olanrele and Agbato (2014) and Thontteh and Omirin (2015), Holden and Ghegu (2016) and Kanji et al. (2005) who also found similar factors as obstacles to land registration in their respective research contexts.

Similarly, the results suggest that the cost of registration needs to be further reduced. Although some respondents said that the cost of registration is little compared to the cost of purchasing a property, for the majority purchasing land is a long-term project for which they have to save for multiple years. To these people, registration is an additional burden which, if possible, should be avoided. If the cost of registration is high relative to the disposable incomes of households, the willingness and ability for land registration is constrained. The result is a lack of information in the land markets which causes market failure. The implication is that land administration reform measures need to give adequate consideration to the costs of land registration bearing in mind the level of disposable incomes of households.

Furthermore, the findings demonstrate that ignorance is a fundamental problem to land registration. Even if the challenges of costs and procedures are adequately addressed, there would still be problems of low land registration because people cannot buy into a system that they are not informed about even if the costs of entry are free. The findings, therefore, suggest that government reform measures should integrate systematic enlightenment programmes to educate people on the need and benefits of land registration. Furthermore, the problem of corruption reflects the widespread unethical business conduct in Nigeria.

The problems associated with registration of titles and the high level of lack of formal titles to land have implications for the land market, especially with respect to security of tenure and ease of land transactions. Without a formal title and evidence to it, proving land ownership is difficult. Consequentially, land market transactions are difficult, resulting in market failures. These failures affect the housing market and worsen housing problems. The implication is the necessity for the government to continue and further advance its land administration reforms to ensure it is in line with best practices.

\section{Conclusion}

The importance of land registration cannot be over-emphasised. Its role in motivating investment in land, providing security of tenure and information for land transactions is essential to economic activities. It should therefore be 
promoted, and steps taken to remove obstacles to its success and advancement. The research has implications for the land and housing markets in Nigeria and Africa in general. The land market is a critical component of the housing market. In Nigeria and several other African countries, most households build rather than buy their homes. To build the homes, they have to acquire land. Land market transactions are therefore important to households. Failures in the land markets worsen housing problems. Land registration plays an important role in enhancing land market efficiency. It is therefore important in addressing urban housing problems in Africa. Insecurity of tenure is one of the consequences of non-registration of land titles and constrains investment in land. Low level of land registration is thus a potential source of urban housing problems.

Moreover, as the results indicate, the challenges to land registration are wide and varied. The implication is that a wide-range of reform measures are necessary to address these challenges to enable the development of efficient land markets and consequently contribute to solving urban housing shortages in African countries. Changing the registration process from the manual to digital system, as is done in some Nigerian states, is essential but not sufficient to address the challenges. More comprehensive reforms are necessary. These should include: educating the public on the necessity and benefits of land registration, developing mechanisms to streamline the land registration process and supply of information for land market transactions, and introducing modes of payment that could lighten the financial burdens of land registration. It is important to state, however, that improving land registration is not sufficient in itself to stabilise the land markets or address the urban housing shortages prevalent in African countries. Measures to deal with poor access to land and housing finance by urban households, inefficient housing policies and the high cost of home building are also necessary.

This research provides a unique insight into land registration problems in Nigeria through an exploration of the views of the government and the people they govern with a method that combines quantitative surveys and qualitative interviews. The research contributes to evidence-based land administration reforms in the country. The results are significant for policymakers in formulating and reviewing reforms in land registration. They are also significant to land transaction consultants in building literacy in land registration among their clients. In addition, the issues raised in the research are equally relevant to many African countries where land registration and insecurity of land tenure have posed significant challenges to the development of the land markets. Thus, the research makes valuable contributions to Africa's land market literature.

The limitation of the study is that it is based on data from urban land transactions. The results may be affected if data from rural land transactions are included. Nevertheless, the inclusion of the KADGIS in the study ensures that such effect is not likely to be significant. Future researchers should consider investigating further measures to address the challenges to land registration in the state. 


\section{References}

Ali, D. A., Deininger, K., \& Goldstein, M. (2014). Environmental and gender impacts of land tenure regularization in Africa: Pilot evidence from Rwanda. Journal of Development Economics, 110, pp.262-275.

Aluko, B. T., Olaleye, A., \& Amidu, A. (2004). Problems of Land Delivery for Housing Development. Globalisation and Construction 2004 (Proceedings of International Symposium of Globalisation and Construction) (pp.601-610). Rotterdam: Fraunhofer.

Babatunde, A. A., Kemiki, O. A., Abdulkareem, S., \& Fabunmi, F. (2014). Analysis of activities of land administration machineries in Abuja and Minna, Nigeria. Journal Of Environmental Science, Toxicology And Food Technology, 8(1), pp.31-38.

Benjaminsen, T. A., Holden, S., Lund, C., \& Sjaastad, E. (2008). Formalisation of land rights: Some empirical evidence from Mali, Niger and South Africa. Land Use Policy, 26, pp.28-35.

Bersaglio, B., \& Kepe, T. (2013). Farmers at the edge: property formalisation and urban agriculture on Dar es Salaam, Tanzania. Urban Forum, 25, pp.389-405.

Centre for Affordable Housing Finance in Africa. (2016). Housing Finance in Africa Yearbook 2016. 7. (S. Sireena, Ed.) Johannesburg: Centre for Affordable Housing Finance in Africa.

Creswell, J. W. (2014). Research Design: Quantitative, Qualitative, and Mixed Method Approaches (4th ed.). Los Angeles: Sage.

De Soto, H. (2000). The Mystery of Capital. London: Transworld Publishers (Black Swan Books).

Deininger, K., \& Feder, G. (2009). Land Registration, Governance, and Development: Evidence and Implications for Policy. The World Bank Research Observer, 24(2), pp.233-266.

Durand-Lasserve, A., \& Selod, H. (2007). The Formalisation of Urban Land Tenure in Developing Countries. Washington, DC: Paper prepared for the World Bank's 2007 Urban Research Symposium, May 14-16.

Feder, G., \& Nishio, A. (1999). The benefits of land registration and titling: economic and social perspectives. Land Use Policy, 15 (1), pp.25-43.

Federal Government of Nigeria. (2004). Land Use Act 1978. Chapter L5 Laws of the Federation of Nigeria 2004.

Federal Ministry of Housing and Urban Development. (2006). Land Administration Reforms: Benefits and Challenges, The Role of the Federal Land Information System (FELIS). Abuja: Federal Ministry of Housing and Urban Development.

Hanstad, T. (1998). Designing land registration systems for developing countrries. American University International Law Review, 13(3), pp.647-703.

Holden, S. T., \& Ghebru, H. (2016). Land tenure reforms, tenure security and food security in poor agrarian economies: Causal linkages and research gaps. Global Food Security, 10, pp.21-28.

Kaduna State Government. (2015). The Kaduna Goepraphic Information Servive (KADGIS) Law, 2015. Kaduna.

Kaduna State Government. (2017). Kaduna Land Use Regulations, 2017. Kaduna. 
Kanji, N., Cotula, L., Hilhorst, T., Toulmin, C., \& Witten, W. (2005). Research Report 1: Can Land Regitration Serve Poor and Marginalised Groups? Summary Report London: International Institute for Environment and Development.

Lawry, S., Samii, C., Hall, R., Leopold, A., Hornby, D., \& Mtero, F. (2014). The impact of land property rights interventions on investment and agricultural productivity in developing countries: a systematic review. Journal of Development Effectiveness, 9(1), pp.61-81.

Ma, X., Heerink, N., Ierland, E., \& Berg, M. (2013). Land tenure security and land investment in Northwest China. China Agricultural Economic Review, 5 (2), pp.281-307.

National Population Commission [NPC]. (2009). 2006 Population and Housing Census of the Federal Republic of Nigeria. Priority Tables Volume I. Abuja: NPC.

National Population Commission [NPC]. (2010). 2006 Population and Housing Census of the Federal Republic of Nigeria. Housing Characteristics and Amenities Tables; Priority Tables (LGA), Vol II. Abuja: NPC.

Nigeria Housing Finance Programme. (2014, August 10). About Us: Nigeria Housing Finance Programme. Retrieved from Nigeria Housing Finance Programme Website: https://www.housingfinance.gov.ng

Nuhu, M. B. (2009). Enhancing Land Titling and Registration in Nigeria. Eilat, Israel, 3-8 May 2009: FIG Working Week 2009.

Nwuba, C. C., \& Chukwuma-Nwuba, E. O. (2018). Barriers to accessing mortgages in Nigeria's housing markets. International Journal of Housing Markets and Analysis, https://doi.org/10.1108/IJHMA-102017-0089.

Olanrele, C. O., \& Agbato, S. E. (2014). Lnad right registration and property development for poverty eradication and slum clearance in Nigeria. Journal of Design and Built Environment, 14(2), pp.1 13.

Payne, G., Durand-Lasserve, A., \& Rakodi, C. (2009). The limits of land titling and home ownership. Environment and Urbanization, 21(2), pp.443-462.

Pinckney, T. C., \& Kimuyu, P. K. (1994). Land tenure reform in East Africa: Good, bad or unimportant? Journal of African Economies, 3(1), pp.128.

Singh, A. S., \& Masuku, M. B. (2014). Sampling techniques \& determination of sample size in applied statistics research: An overview. International Journal of Economics, Commerce and Management, 2(11), pp.1-22.

Sjaastad, E., \& Cousins, B. (2008). Formalisation of land rights in the South: An overview. Land Use Policy, 26, pp.1-9.

The World Bank. (2009). Housing Finance. Making Finance Work for Nigeria. Washington, DC., USA: World Bank. Retrieved May 11, 2011

from http://siteresources.worldbank.org/INTAFRSUMAFTPS/Resources/ Making_Finance_Work_for_Nigeria.pdf.

The World Bank. (2012). Doing Business 2012: Doing Business in a More Transparent World. Washington, DC: The World Bank/ the International Finance Corporation. 
Thontteh, E. O., \& Omirin, M. M. (2015). Land Registration Within the Framework of Land Administration Reform in Lagos State. 21st Pacific- Rim Real Estate Society Conference. Kuala Lumpur, Malaysia, 18-21 January, 2015.

Tibaijuka, A. K. (2004). Africa on the Move: An Urban Crisis in the Making. A Submission to the Commission for Africa. Nairobi: United Nations Centre for Human Settlements (UN Habitat). Retrieved March 18, 2011 from http://www.unhaabitata.org/downloads/docs/462683992.

Toulmin, C. (2009). Securing land and property rights in sub-Saharan Africa: the role of local institutions. Land Use Policy, 26(1), pp.10-19.

UN-Habitat/OHCHR. (2016). Habitat III Isuue Papers, 9 - Urban Land. New York: UN-Habitat/OHCHR.

United Nations Department of Economic and Social Affairs. (2014). World Urbanisation Prospects: The 2014 Revision - Highlights. New York: United Nations.

United Nations, Department of Economic and Social Affairs, Population Division. (2014). World Urbanisation Prospects: The 2014 Revision, CD-ROM Edition. United Nations.

United Nations, Department of Economic and Social Affairs, Population Division. (2015). World Population Prospespects: The 2015 Revision, DVD Edition. United Nations. 
Appendix

Questionnaire for Research on Access to Land

Where appropriate, please mark $\mathbf{X}$ against the option you choose or fill in the space as appropriate

\section{Section A: Respondent's Profile}

Please supply the following information concerning yourself

1) Sex

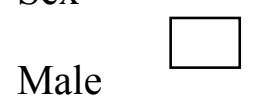

2) Marital Status

Married

Female

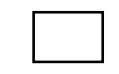

3) To which of the following age brackets do you belong?

Less than $30 \square \quad \square 0$ to $39 \square \quad \square \quad$ to $49 \square$ and above

4) What is your highest educational qualification?

None $\square$ Primary school $\square$ Secondary school (or equivalent)

Degree or other higher education qualifications

5) How many years have you worked?

6) Please state the number of persons currently living with you

7) What is your income per month ?

8) What is the income of your spouse (if any) per month $?$

Section B - Tenure Status and Land Acquisition Sources

In the table, please tick the option that applies to you

\section{Tenure Status}

9) Which of these categories do you belong to?

a) Owner-occupier (living in your own house)

b) Tenant building your own house

c) Tenant owning land but yet to start building

d) Tenant not owning land but planning to acquire

How land was Acquired

10) If you have land or house state how you acquired the land

a) Direct State Government allocation

b) Direct Local Government allocation

c) Purchase from private landowner

d) Inheritance from family/community land

e) Other sources (please specify) 


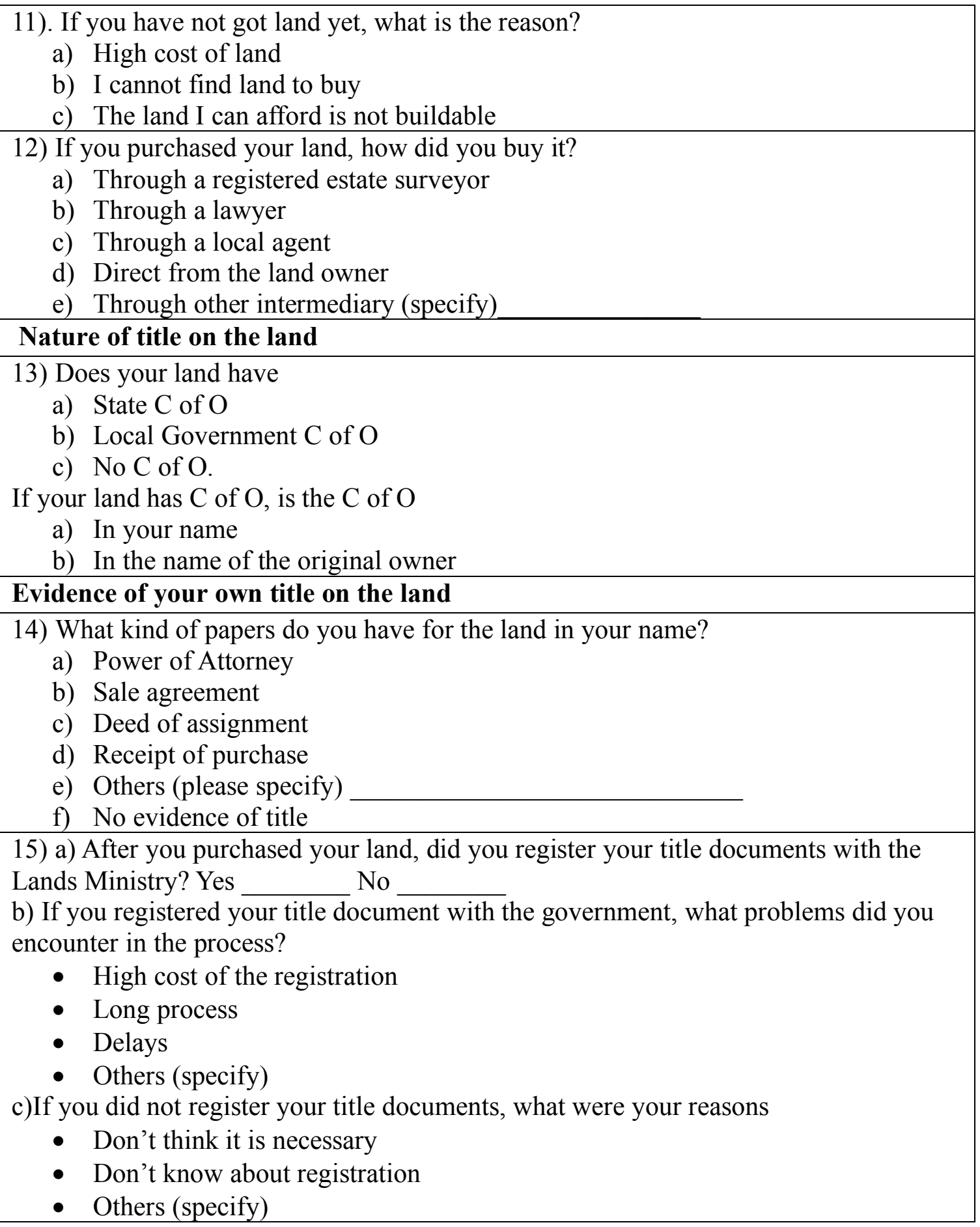

